\title{
Reengineering English Language Teaching: Making the Shift towards 'Real' English
}

\author{
María Luisa Pérez Cañado (Corresponding author) \\ Department of English Philology, University of Jaén \\ 23071 Jaén, Spain \\ Tel: 34-953-21-1825Ｅ-mail: mlperez@ujaen.es
}

\begin{abstract}
This article underscores the importance of keeping up to date with vocabulary which is currently employed in English-speaking countries. It argues that textbooks, dictionaries and even corpora are not the most reliable sources to do this, and puts forward a pedagogical proposal - grounded in the Lexical Approach and three pedagogical innovation projects - to incorporate 'real' English into the language classroom. After clarifying what is meant by such 'real' English expressions and providing a possible classification for them, it suggests diverse sources of 'real' English input including telecollaboration, sitcoms and TV series, podcasts, Internet texts, and recent bestsellers -, and subsequently presents a set of tried-and-true activities to exploit them, activities which allow the incorporation of pedagogically innovative approaches into the ELT classroom. The ultimate aim is to link the classroom with what goes on beyond its confines and to make our students' lexical competence approximate that of native English speakers.
\end{abstract}

Keywords: English language teaching, Vocabulary, Pedagogical innovation

\section{Introduction}

It is a known fact that "No language stays still" (Eaves-Walton 1999:6) and that "All languages change" (Swan 2005:4). This is particularly the case of the English language. Linguistic change is currently sped up by rapid worldwide communication, travel, or the media, and in the case of English, it is heightened by its global presence and lingua franca status. The result is pinpointed by Crystal (2000:6): "there has never been such a period of rapid and fundamental change since the explosions of development that lit the [English] language in the Middle Ages and the Renaissance".

This change is particularly conspicuous in the English lexicon; both Eaves-Walton (ibid) and Swan (ibid) document ongoing lexical innovation. Crystal (ibid:3) also underscores this point: "The bulk of the new distinctiveness of English is in vocabulary - by which I mean not just new words, but new meanings of words, and new idiomatic phrases".

It thus becomes incumbent upon us, as English teachers, to be up to speed with these new lexical chunks that are constantly entering the English language. Swan (ibid:6) subscribes the need to "keep an eye on what is happening" with a dual purpose: to answer the questions our students may have about these novel expressions and to modify our explanations when and where necessary. However, we believe keeping up to date with 'real' English expressions should have a more lofty goal: to make these lexical phrases part of our students' receptive and, hopefully, productive vocabulary, to ensure they do not make the effort to learn and use expressions which are stilted and obsolete, like the invariably taught 'It's raining cats and dogs' in Spain. If we seek for our students to emulate the language of native speakers (Widdowson 2008), we need to overcome the 'It's raining cats and dogs' syndrome in lexical acquisition.

How to go about this? Traditional answers are no longer acceptable. For example, one suggested possibility (Swan: ibid) is for authors of language textbooks, grammars, and dictionaries to be alert to language change in order to be responsive to it in their works. Swan also underlines the utility of language corpora to revamp language descriptions. However, we fully endorse Widdowson's (ibid) recent claim that dictionaries are limited in capturing the reality of English language in use. If English is a "patchwork of prefabricated phrases", dictionaries provide only a reduced account of this patchwork. Exemplification in dictionaries is often old-fashioned. Even in corpora, much of what is encountered may not be in use at all in present production. Thus, we need to look elsewhere for the solution.

Another oft-cited source of updated 'real' English are study abroad programmes. The latter, deemed essential in the current European and North American literature (Bologna Declaration 1999; Pratt et al. 2008), involve study periods in English-speaking countries, where direct contact with native speakers of the language can favour picking up English which is actually used. This option, while naturally being both valuable and useful, is not always the most desirable one for us as English teachers for four main reasons. 
First, with the dramatic increase in international mobility, going to an English-speaking country is no longer a guarantee that we will encounter native-speaking individuals in the traditional places where students previously had the chance to practise the language (e.g. shops or restaurants). In this increasingly "global village", it is common to find ourselves "in direct contact with dissimilar others in our neighbourhoods, schools, and workplace" (Ting-Toomey 1999:7). And even when direct encounters with native speakers do occur, we cannot guarantee our students will recognize or be aware of recent English expressions which they should incorporate into their lexicon. We need to find a way to raise their explicit attention to their existence and use. Plus, native speakers are not always the best source of updated English - their language can be just as stilted if they have been out touch with it for a period of time. In Eaves-Walton's terms (op.cit.:6), for a native speaker, “a 'slip' may just be evidence of English getting past its 'sell-by date' - and that's an expression I wouldn't have used ten years ago!’. Finally, these sojourns to English-speaking countries are beyond our scope as language teachers - as Seidlhofer (2002) puts it, our aim is for students to incorporate the lexicon they receive as input in the classroom. The latter is our arena and we need to reflect on what we can do within it to foster 'real' English learning and use.

This is precisely the aim of the present article: to offer a selection of tried-and-true ways for teachers of English to overcome the 'It's raining cats and dogs' syndrome in their classrooms. The paper will begin by clarifying what we mean by 'real' English vocabulary and by outlining what kinds of words and lexical phrases can be taught. The rationale in which this proposal is grounded shall then be presented, together with the three pedagogical innovation projects within which its didactic aspects are framed. The methodological suggestions for keeping up to date with and teaching these 'real' English expressions shall then be fleshed out, and the most outstanding conclusions will be drawn in the final section of the article.

\section{What is 'real' English vocabulary?}

The concept of 'real' English vocabulary involves single words and, especially, multi-word items which are currently employed in conversational English by native speakers of the language. They are often colloquial in use and enhance the native-like quality and fluency of the language of those who incorporate them into their productive vocabulary. To furnish an initial example, we often teach our students to respond to the common social formula 'How are you?' with expressions such as 'I'm very well, thank you. And you?', whereas in 'real' (American) English, the answer would be 'I'm good, thanks'. Responding with the first option will only draw attention to the fact that the speaker does not pragmatically master the English language, whereas, in the second case, (s)he will be approximating the actual conventions of native English speakers.

While we fully endorse teaching general vocabulary related to the specific semantic fields which each concrete EFL subject requires, as well as expanding the academic lexicon of our students, we also subscribe the need to feed them this 'real' English vocabulary so that they not only recognize it when they encounter it, but also use it productively in their conversations.

As was previously mentioned, this vocabulary can take the form of single words, but pre-eminently of multi-word items, including collocations, phrasal verbs, gambits used to express functions, idiomatic expressions (including what Carter 1987 terms full idioms and semi-idioms), and lexical phrases or prefabricated routines. We also advocate familiarizing students with certain acronyms (or 'netcronyms', as they are coming to be called) of widespread use in electronic communication and which could function as sentence builders (Nattinger and DeCarrico 1992) or sentence frames (Lewis 1997). The following table provides instances of each of these types of 'real' English words or phrases.

\section{Insert Table 1 here.}

\section{Background and rationale}

Our categorization of 'real' English lexicon is thus grounded in the increasingly acknowledged Lexical Approach (Nattinger and DeCarrico: op.cit.; Lewis: op.cit.). Considered a 'promising new direction for language teaching' (Nattinger and DeCarrico op.cit.:1) over 15 years ago, the Lexical Approach has become a sanctioned and prevalent approximation to language teaching. It maintains that the lexical chunk or phrase (a group of up to 8 words that conveys pragmatic meaning in a specific community) is the "ideal unit which can be exploited for language learning" (Nattinger and DeCarrico op.cit.:1).

Lexical chunks are pervasive in adult and child language, as well as in L1 production, and they present many advantages for language acquisition (Pérez Cañado 2002). They have an economizing and motivational role, they are seen as the basic organizing principle in language production, and are significant for lexical storage and retrieval. Lexical phrases are held to be the key to comprehensibility, efficient acquisition, and effective communication, as well as to fluency. The difference between speaking English well and very well is to be found in the much larger stock of ready-made expressions stored in the speaker's mental lexicon and which (s)he can pull out automatically. Hence, the expansion of our students' stock of multi-word units should be an essential objective in the language classroom, and it is through them that 'real' English materializes. 
Our pedagogical proposal for implementing them is framed within three governmentally-financed pedagogical innovation projects developed with pre-service English teachers at the University of Jaén in Spain. The first of them, $L a$ utilización de las nuevas tecnologías en la metodología ECTS: el caso de la telecolaboración (2006-2007), used computer-mediated communication (CMC) and virtual learning environments (VLE) - the Blackboard platform - to establish a telecollaboration (TC) exchange between freshmen at the University of Jaén and pre-service language instructors at Southern Methodist University in Dallas. Together, they had to co-operate on a weekly basis to accomplish a clear-cut set of tasks, with a primarily linguistic focus. The Dallas tutors provided language-related feedback to the Spanish English Philology freshmen, thus making the experience a language-based e-tutoring one.

In turn, the second pedagogical innovation project, Las TIC en el ECTS: el desarrollo de la competencia léxica a través de la enseñanza virtual (2006-2007) has also made use of a virtual learning environment - in this case, the ILIAS platform - to try to improve English Philology students' lexical competence in English. On the basis of popular and recent sitcoms and TV series which the students themselves selected (e.g. Family Guy, Friends, House, CSI Las Vegas, Hot Properties), a batch of original vocabulary activities has been designed to expand and reinforce the vocabulary of the main lexical fields which the students are expected to master (e.g. family, health, crime, technology, marriage). They have been completed on the ILIAS platform, combined with face-to-face interaction, thus drawing on blended learning.

The final project, INNOFIL: La innovación docente en Filología Inglesa en el marco del EEES (2007-2009), has also attempted to improve the lexical competence of English Philology students, as alarmingly low results in this area were detected in the academic years prior to 2004-2005. Now, podcasts and extremely updated Internet texts have been employed to work on 'real' English, as well as to develop the listening and reading comprehension of our pre-service English teachers. Blended learning has once again permeated the experience.

\section{How to teach 'real' English: Pedagogical proposals}

We now use these pedagogical innovation projects as a basis to illustrate how 'real' English words and, especially, lexical phrases can be taught, and the main sources from which they can be drawn.

\subsection{Using telecollaboration}

Having our students correspond on a regular basis with a native English-speaking tutor within the classroom context is an ideal way of accessing 'real' English. Not only do they have the possibility of communicating (orally and in writing) with a native speaker their age; we as teachers have the chance to monitor and guide their performance in order to keep the project on target, since each exchange is recorded on the platform for our subsequent supervision. Thus, we can steer our students' interactions, raising their awareness to the expressions we consider relevant, while at the same time boosting their autonomy and capacity for cooperation.

Our students made the most of the TC experience by asking their tutors grammatically related questions, cultural queries, and, of course, lexically-driven inquiries (Pérez Cañado and Ware 2009). In this sense, the Spanish pre-service teachers explicitly asked their e-tutors to provide them with 'real' English expressions in their exchanges:

Q: Please send me more vocabulary you use normally and I ask you for the next mail info about the phrasal verbs, I want you to send me the more common or usual phrasal verbs that I'm supposed to know!

A: I love my friends, and I think we'll be hitting up (going to) the drive-in very soon! We try to vary our weekend activities so we don't get bored. [...] I attached a song by a band I'm pretty obsessed with right now, and I'm so stoked (excited) about seeing them in concert in two months! [...]

About the phrasal verbs, I found this very useful website a few weeks ago. Here's the link: http://www.englishpage.com/prepositions/phrasaldictionary.html

Let me know if you have any problems understanding or navigating the website, but I thought I'd pass it along for quick reference.

Also, the words I highlighted are slang words I found when I reread my post to you. I included their definition in case you're unfamiliar with them, but also let me know what other kind of vocabulary you'd like to learn (anything specific) or if I forget to define a word you don't know.

And, even more interestingly, they began to use them productively themselves, thereby making the transition from what Krashen (1999) terms learning to acquisition:

- $\quad$ Happy New Year!!!! Perhaps it's a bit late, I know. Anyway, how was your Christmas?? I hope you have had a good time with your family and friends and you have relaxed. I have stayed at home. I celebrated Christmas Eve having dinner with my family and then, hung out with my friends. 
- Hi again. How's it going? I hope good. I'm writing to you because I need help on the two previous exercises. They're a report and a discussion. I've lost a lot of time, so I would like to catch up with my work. I would like you to provide examples of each and correct mine. I hope you don't get worked up. Thanks in advance.

They also claimed to have picked up expressions from the e-mails their Dallas partners sent them (especially opening, closings, and netcronyms), which they then began to use themselves: "while I talk or send an e-mail, I find I use some expressions or new words I have learned, unconsciously'. This is especially relevant, since, as Pennock-Speck asserts (2009:175), "a significant part of the information we receive and send comes to us through emails, attachments, web pages, and so it s particularly apt for students to learn [...] through a computer-mediated communication system".

A useful way of supplementing a TC experience of this nature is with what we call a face-to-face 'coffee and talk' session. Here, we invite a group of 10 to 15 native English speakers from different backgrounds (American, English, Irish, Canadian) to talk in an informal environment with our Spanish students, thereby also promoting the encounter with 'real' English expressions.

\subsection{Making the most of sitcoms and TV series}

Recent and popular sitcoms and TV series are another invaluable means, from our experience, to focus on 'real' English vocabulary. They are an extremely motivating way of providing exposure to actually used and updated expressions in different varieties of English, as the latter is used by a hugely diverse community of speakers and each one will have its functioning or operative variety (Harmer, 2009). Thus, sitcoms need not be limited to the standard American or British ones, but can also instantiate the so-called 'world Englishes', including not only Scottish or Irish accents and vocabulary, but also South African, Indian, or even Nigerian English, through the use of series, movies, or clips from, e.g., Bollywood or Nollywood. This will help students become familiarized, from a receptive point of view, with the language which is actually used outside the confines of the classroom and, from a productive one, to foster their fluency through the use of such expressions. In our project, explicit attention was drawn to such lexical phrases through diverse activities in a virtual learning environment. Following the pedagogical principles of the Lexical Approach (Nattinger and DeCarrico: op.cit.; Lewis: op.cit.), we have employed the following types of exercises:

Gap-filling:

\section{Insert Figure 1 here.}

- Translation of 'real' English chunks:

\section{Insert Figure 2 here.}

- $\quad$ Guessing from context through discovery-based procedures aided by computer corpora:

\section{Insert Figure 3 here.}

Productive practice:

\section{Insert Figure 4 here.}

\subsection{The value of podcasts and Internet texts}

These same types of activities can and have been employed to teach 'real' English expressions drawn from other sources: podcasts and Internet texts. The possibilities offered by the WorldWideWeb in this sense are unique: unlimited access to extremely updated written texts and auditory files which focus on motivating topics for our students and which directly connect to the main semantic fields we need to cover in class.

Again, to provide specific instances, one of the first topics which our students need to master involves physical descriptions and clothes. We have expanded this lexicon and focused on 'real' English expressions related to it through the text 'Oscars 2008: Fashion and Make-up Recap!' (available at http://lifeofaladybug.typepad.com/the_life_of_a_ladybug/2008/02/oscars-2008-fas.html) and through the podcast '2008 Academy Awards Fashion Wrap' (available on Youtube). Both provide a fun post-mortem on the physical appearance of some of the stars our students admire most and allow the introduction of a vast gamut of 'real' English expressions (e.g. 'He is some hotness!' when describing Patrick Dempsey or 'She is a fave' when alluding to Marion Cotillard). Youtube is also a priceless source of documents to work on updated English in a motivating way: for example, we have used some medicine commercials currently showing in the States (e.g. Zyrtec, Singulair, Advil) to work on vocabulary related to health from a different perspective to that provided by the textbook.

\subsection{Championing all types of literature}

A final invaluable source of 'real' English input involves, in our experience, recent bestsellers and the oftentimes disparaged 'airport literature'. Recently written books by bestselling authors from diverse English-speaking backgrounds (e.g. Marian Keyes, Sophie Kinsella, Lauren Weisberger, Jennifer Weiner) are perfectly valid and extremely useful for students to receive extensive input of actually used English. Their attention to lexical chunks can 
then be drawn via activities which explicitly target those expressions of interest to us. Merely reading such literature, however, has proved beneficial for vocabulary acquisition, as Krashen (op.cit.:58-60) documents with case histories of readers. Four subjects (three speakers of Korean and one of Spanish) found their reading experiences to be extremely helpful in understanding television and telephone conversations, in reading much more speedily and effortlessly, and in speaking easily, confidently, and without hesitation. As Krashen puts it, "They reported enjoying the reading enormously, made impressive gains on tests of vocabulary, and reported great improvement in their English" (op.cit.: $58)$.

\subsection{Towards pedagogical innovation in teaching 'real' English}

The afore-mentioned activities for working on 'real' English lexical chunks are clearly in line with the pedagogical principles of the Lexical Approach (Nattinger and Decarrico: op.cit.; Lewis: op.cit.). The overwhelming majority of scholars in this field are invariably in favour of the overt, explicit, and formal teaching of these items, endorsing the importance of raising students' awareness of their existence. They propound teaching them following discovery-based procedures with the aid of corpora; through translation, gap-filling exercises, and extensive reading and listening; and by making language lessons a combination of input, awareness-raising, learner training, and language practice, which is exactly what we have done through the means outlined in the previous three subheadings of this section. The need for high-quality input is also emphasized by Lewis (op.cit.), something which can successfully be provided through the sources we have presented.

However, the Lexical Approach is not the only recent method which is incorporated in our proposal for teaching 'real' English. Cooperative Learning clearly comes into play in telecollaboration, as the students on both ends of the exchange must work together to achieve a joint outcome for which they are both accountable. The fact that this observable outcome is the result of a set of clear-cut tasks also brings Task-Based Learning (TBL) into the picture. Autonomous or Lifelong Learning (LLL), so trendy now in the European context, equally come to the fore, as the bulk of the activities the students are expected to complete in the virtual learning environments and through computer-mediated communication are done outside the classroom, within their private or individual study time, albeit under the guidance of the instructor. Computer-Assisted Language Learning (CALL) and blended learning obviously run through the experience, via the use of VLE, CMC, and web-based authentic material (e.g. podcasts and Internet texts). Finally, Communicative Language Teaching (CLT) pervades the pedagogical proposal, as the aim is precisely to link classroom learning to what goes on beyond its confines to the greatest extent possible, the onus being on using 'real' English expressions in oral and written communication.

\section{Conclusion}

In the English teaching profession, we often tend to rely excessively on the textbook, the dictionary, or even the linguistic corpus. In this article, we have argued that these sources are no longer valid in making the link with the 'real' English language which is currently being used beyond the confines of the classroom, especially at a time of tremendous linguistic change like the one we are living. After clarifying what we mean by such 'real' English lexical chunks and classifying them, we have put forward a pedagogical proposal for keeping up to date with English vocabulary in the ELT classroom. Diverse sources of input, such as telecollaboration and 'coffee and talk' sessions with native English speakers, sitcoms and TV series, podcasts, Internet texts, and recent bestsellers, have been suggested, together with possible ways to exploit them in line with trendy language teaching methods - CALL, blended learning, cooperative learning, autononomous and lifelong learning, CLT, or TBL - which favour pedagogical innovation.

Language teachers, perhaps more than any other teaching profession, have to constantly check the pulse of what is happening with their object of study. We have to be, in Swans's terms (op.cit.:6), "English watchers". We hope the ideas put forward in this article can work towards attaining this important endeavour. Only then will we be able to confidently send our students out into the English-speaking world and reframe ourselves back into relevant English language teaching.

\section{References}

Carter, R. (1987). Vocabulary. Applied linguistic perspectives. London: Allen \& Unwin Publishers Ltd.

Crystal, D. (2000). Emerging Englishes. English Teaching professional, 14, 3-6.

Eaves-Walton, F. (1999). Native speakers get it wrong. English Teaching professional, 12, 6-7.

European Ministers of Education. (1999). The Bologna Declaration. [Online] available: http://www.bologna-bergen2005.no/Docs/00-Main_doc/ 990719BOLOGNA_DECLARATION.PDF (July 7, 2009).

Harmer, J. (2009). Ease up the slap: Language and discourse in the ESOL classroom. Plenary conference at the 32nd Annual TESOL-Spain Convention: "Blending Tradition with Innovation". Seville, Spain.

Krashen, S. D. (1999). Three arguments against whole language and why they are wrong. Portsmouth: Heinemann. 
Lewis, M. (1997). Implementing the lexical approach. Putting theory into practice. Hove: Language Teaching Publications.

Nattinger, J. R. \& DeCarrico, J. S. (1992). Lexical phrases and language teaching. Oxford: Oxford University Press.

Pennock-Speck, B. (2009). European convergence and the role of ICT in English Studies at the Universitat de València: Lessons learned and prospects for the future. In M. L. Pérez Cañado (Ed.), English language teaching in the European Credit Transfer System (pp. 169-185). Frankfurt am Main: Peter Lang.

Pérez Cañado, M. L. (2002). Introducing the lexical approach. GRETA. Revista para Profesores de Inglés, 10/2, 19-26.

Pérez Cañado, M. L., \& Ware, P. D. (2009). Why CMC and VLE are especially suited to the ECTS: the case of telecollaboration in English Studies. In M. L. Pérez Cañado (Ed.), English language teaching in the European Credit Transfer System (pp. 111-150). Frankfurt am Main: Peter Lang.

Pratt, M. L., Geisler, M. Kramsch, C., McGinnis, S., Patrikis, P., Ryding, K., \& Saussy, H. (2008). Transforming college and university foreign language departments. The Modern Language Journal, 92/2, 287-292.

Seidlhofer, B. (2002). Pedagogy and local learner corpora: working with learning-driven data. In S. Granger, J. Hung, \& S. Petch-Tyson (Eds.), Computer learner corpora, second language acquisition and foreign language teaching (pp. 213-234 ). Amsterdam: Benjamins.

Swan, M. (2005). What is happening in English? English Teaching professional, 40, 4-6.

Ting-Toomey, S. (1999). Communicating across cultures. New York: The Guilford Press.

Widdowson, H. (2008). Setting a good example. Conference given in honour of Dr. Neil McLaren, Granada, Spain.

Table 1. Examples of 'real' English words and multi-word items

\begin{tabular}{|c|c|}
\hline \multirow{3}{*}{ Words } & Whatever! \\
\hline & A rip-off \\
\hline & Awesome! \\
\hline \multicolumn{2}{|c|}{ Multi-word items } \\
\hline \multirow{4}{*}{ Collocations } & A rave review \\
\hline & Pretty bad \\
\hline & Drop-dead gorgeous \\
\hline & Way better \\
\hline \multirow{6}{*}{ Phrasal verbs } & To freak someone out \\
\hline & To hang out with someone \\
\hline & To blow someone off \\
\hline & To check someone out \\
\hline & How are you holding up? \\
\hline & It just doesn't add up. \\
\hline \multirow{5}{*}{ Gambits used to express functions } & Right back at you! (To respond to a compliment) \\
\hline & Here's the thing. (To introduce a topic) \\
\hline & Will you finish already?! (To express impatience) \\
\hline & $\begin{array}{l}\text { Is this good or what? } \\
\text { How weird is that? } \\
\text { (To ask for agreement) }\end{array}$ \\
\hline & You really don't want to go there. (To give advice) \\
\hline \multirow{4}{*}{ Idiomatic expressions } & To take a raincheck \\
\hline & It's a no-go. \\
\hline & Cut me some slack! \\
\hline & That goes without saying. \\
\hline \multirow{4}{*}{ Lexical phrases or prefabricated routines } & It's so last year! \\
\hline & It's your call. \\
\hline & Not going to happen! \\
\hline & Dream on! \\
\hline \multirow{4}{*}{ Acronyms } & FYI \\
\hline & FWIW \\
\hline & BTW \\
\hline & IMO \\
\hline
\end{tabular}




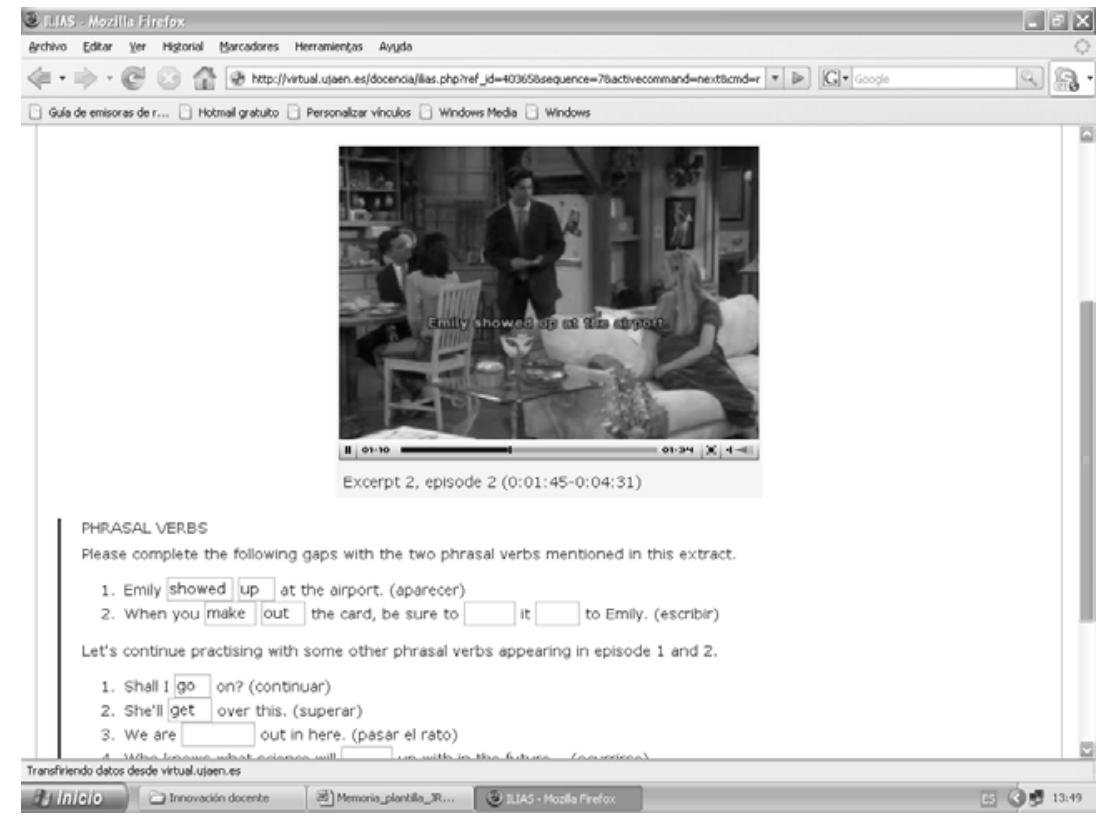

Figure 1

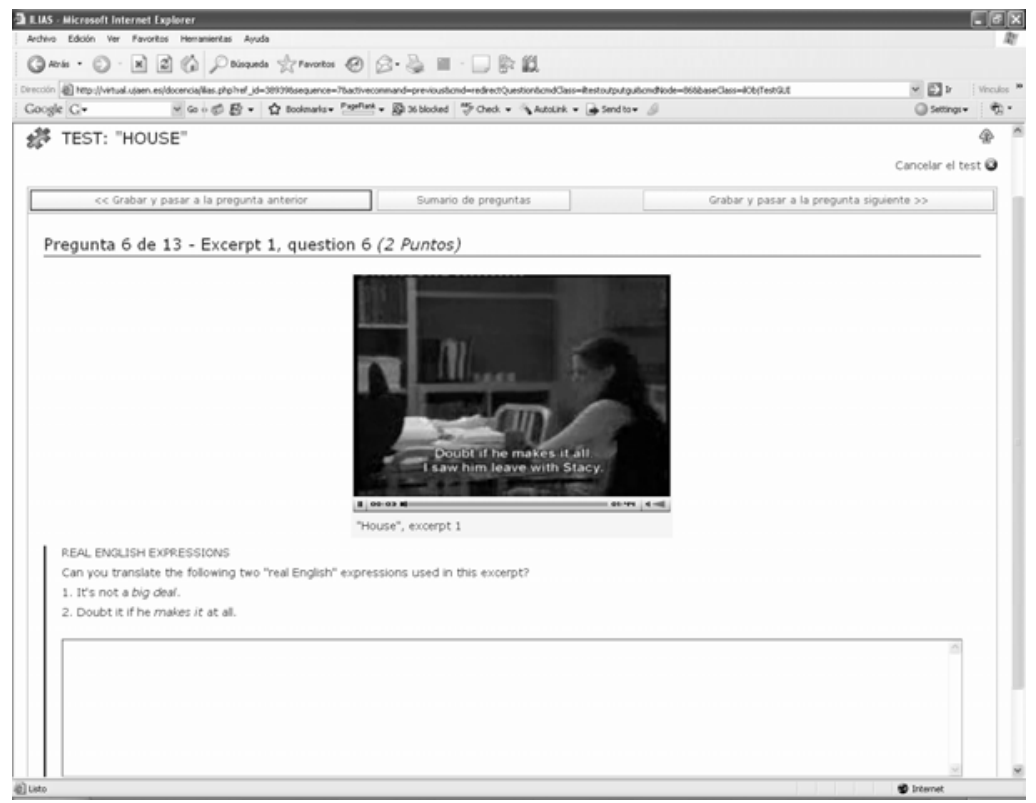

Figure 2 


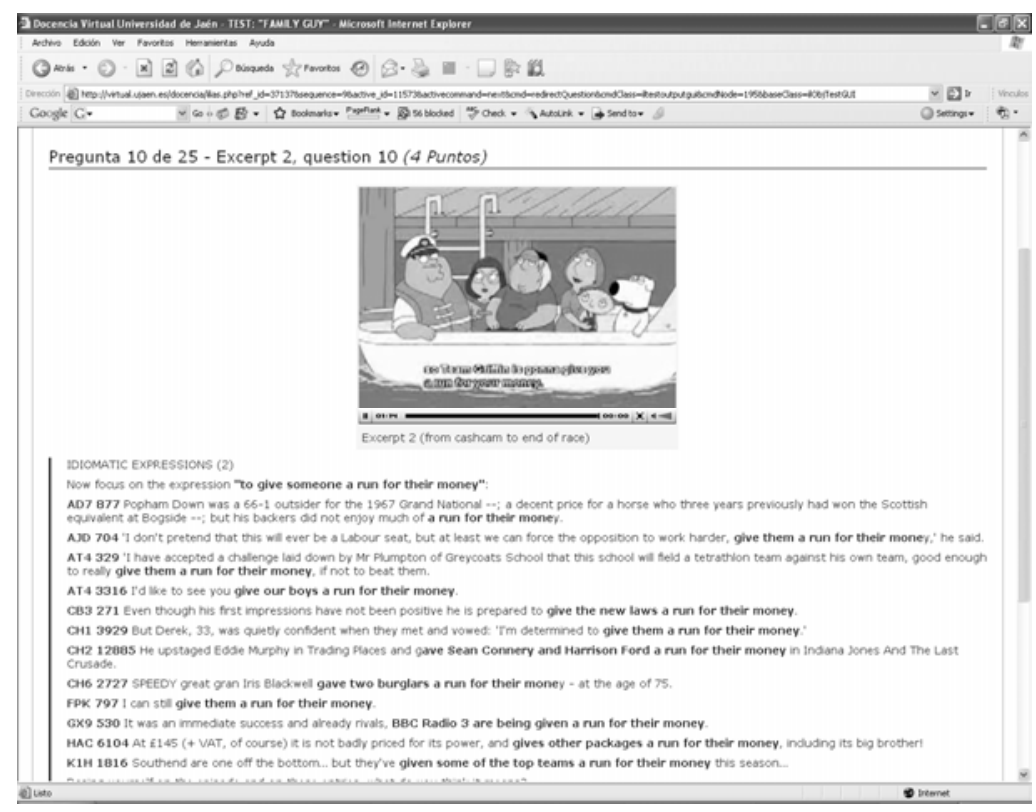

Figure 3

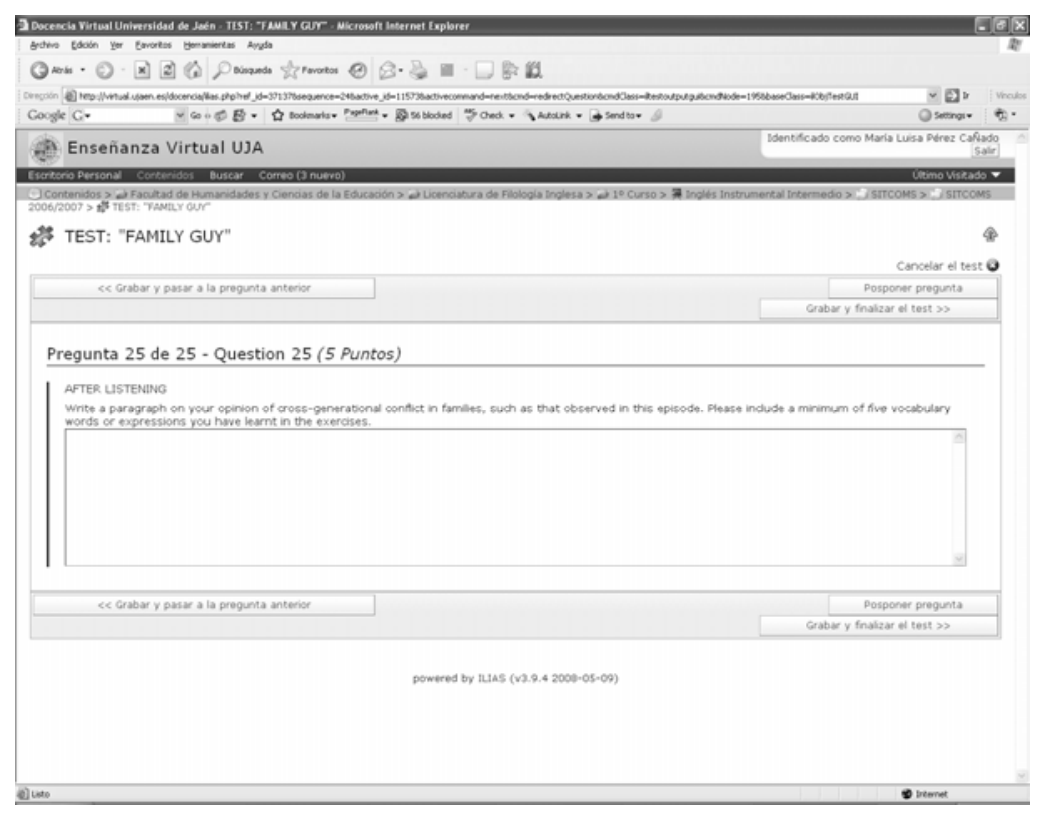

Figure 4 